\title{
INTERNATIONAL BUSINESS BOOKS/PUBLICATIONS RECEIVED BETWEEN JULY 1, 2001 AND SEPTEMBER 30, 2001
}

Asia-Pacific Issues in International Business, Sidney J. Gray, Sara L. McCaughey, William R. Purcell (editors), Edward Elgar, Northampton, MA (2001) \$80.00 US.

Brand Medicine: The Role of Branding in the Pharmaceutical Industry, Tom Blackett, Rebecca Robins (editors), Palgrave, New York, NY (2001).

Business Network Learning, Hakan Hakansson, Jan Johanson, Elsevier Science, Oxford, UK (2001).

Corporate Strategies for Southeast Asia After the Crisis: A Comparison of Multinational Firms from Japan and Europe, Jochen Legewie, Hendrik Meyer-Ohle (editors), Palgrave Global Publishing at St. Martin’s Press, New York, NY (2001) \$65.00 US.

International Business: European Dimensions, Michael D. Hughes, James H. Taggart, Palgrave, New York, NY (2001).

Inward Investment, Technological Change and Growth: The Impact of Multinational Corporations on the UK Economy, Nigel Pain (editor), Palgrave Global Publishing at St. Martin's Press, New York, NY (2001) \$79.95 US.

Japan's Real Estate Investment, M.A. Hines, Quorum Books, Westport, CT (2001) $\$ 65.00$ US.

Keiretsu Economy-New Economy? Japan's Multinational Enterprises from a Postmodern Perspective, Rainer Kensy, Palgrave, New York, NY (2001).

Market Revolution in Latin America: Beyond Mexico, Masaaki Kotabe, Ricardo P.C. Leal (editors), Elsevier Science, Oxford, UK (2001).

Maximizing Human Intelligence Deployment in Asian Business: The Sixth Generation Project, John B. Kidd, Xue Li, Frank-Jurgen Richter, Palgrave, New York, NY (2001) $\$ 69.95$ US.

New Developments in Productivity Analysis, Charles R. Hulten, Edwin R. Dean and Michael J. Harper (editors), University of Chicago Press, Chicago, IL (2001).

Prudential Supervision: What Works and What Doesn't, Frederic S. Mishkin (editor), University of Chicago Press, Chicago, IL (2001).

Take Your Partners: Orion, The Consortium Banks and the Transformation of the Euromarkets, Richard Roberts, Christopher Arnander, Palgrave Global Publishing at St. Martin's Press, New York, NY (2001) \$49.95 US. 